\title{
A study on connectivity and accessibility between tram stops and public facilities
}

\author{
K. Hirano \& Y. Kitao \\ Kyoto Women's University, Kyoto Japan
}

\begin{abstract}
The purpose of this paper is to understand urban structures in terms of the tram network. We then decided to incorporate the idea of connectivity and accessibility between public facilities and tram stops. We will also consider how European cities, which are building world class public transportation systems, use the tram network in relation to the public facilities. We chose tram-type cities which have no subway system, but have a bus system in the west European countries. We focused on twenty-four cities, because of the population of the target cities are from one hundred thousand to two hundred thousand, which is an adequate size for one large-scale community. In order to analyze the relationship, we made the 'pedestrian accessible area' from a tram station in the city, and we then analyzed how many public facilities and pedestrian streets are in this area. As the result, we were able to compare the urban space structure in terms of accessibility and connectivity between tram stops and public facilities among these cities. We can understand features of the inter-relation between urban space and urban facilities. We were able to evaluate which city is the most pedestrian orientated city. Finally, we were able to make five categories of tramtype cities. These findings help us to recognize the urban space structure of the cities, to improve city planning in Japan.
\end{abstract}

Keywords: tram network, community, urban facilities, European city.

\section{Introduction}

\subsection{The purpose and backgrounds}

The purpose of this paper is to understand urban structure in terms of tram networks. In order to achieve the concept of a 'compact city' as a sustainable society, the role of the tram network is important for the pedestrian activities of 
the citizens. The connections between the tram network and public facilities should be considered when we perform city planning. We will discuss the city planning method in which we are able to deal with urban facilities and tram network as a package. We call this approach the 'package approach' Recently in order to make pedestrian orientated urban space, the importance of the 'package approach' is increasing. This design approach plays a role in making/re-building the cities, but we do not have enough experience and knowledge in order to efficiently perform city planning. The subject of this paper is how we could make the 'package' when developing city planning and transportation politics. What kinds of public facilities, such as pedestrian streets and social welfare facilities, should be closely associated with tram-stops?

In Europe the public transportation system plays a very important role in making a sustainable society [1]. According to a discussion that took place at the IFOU Seminar, Prof. Jürgen Rosemann (TU-Delft) discussed what would be important after the welfare society [2]. He discussed how there are 8 European cities out of 10 cities in the world in which we have a high level of conformability to the living environment. There are three reasons why these ten cities are appreciated, 1) social integration, 2) good environment, 3) mobility. The role of architects and city planners is to contribute to establishing a multi cultural society in which diversity will be accepted. This mission of architects will be raised after the having established the welfare society. In order to achieve 'social integration', the role of social housing is very important. To maintain a good environment, eco-orientated building technology will be developed by architects more widely. There are many chances for the architects to work towards making a sustainable society. Mobility within the city will give the citizens freedom for urban activities. These three points are very important issues in order to make the sustainable society.

We are aiming to create a harmonious urban transportation system by considering the environmental issues and sustainable society in Europe [3, 4]. In order to reach this goal, the importance of the tram network is growing. The 'package approach' of which city planners and architects are able to make a strategy for city planning, including the public transportation system, is a positive method in order to re-develop the cities and urban facilities [5]. Many specialists and engineers are making the plans of public transportation systems in Japan, learning from the rich experiences of European cities. For the purpose of making public transportation plans for Japanese cities, we need to understand how the transportation system is integrated into the cities. The urban structure of the tram orientated cities show us good examples. We then focus on the tram type cities which do not have a subway/underground, but in which tram and local bus systems are used. We will also discuss the possibilities of the package approach.

\subsection{Previous studies in Japan}

The previous studies have been seen in the academic domain of transportation system, city planning, environmental planning, geography, political science and 
urban landscape [6. 7]. Among these academic domains several studies are close to our study. For example, Dr. Doi showed the possibility of using Light Rail Transit (LRT) for enhancing commercial activities in at the central area of the city [8]. He explained the role of LRT in making a sustainable society. Dr. Nishimura applied politics onto the public transportation in Western countries, and he showed the role of the tram network for improving urban traffic issues [9]. Dr. Matsunaka examined several aspects of social values on the tram system of Strasbourg (France) as a good example of re-building a tram network for the city. He analyzed several effects caused by the LRT system on the commercial activity, the changed opinions of the citizens, and so on. He discussed the diversity of social efficiency of the LRT system by using this experience $[10,11]$.

Most of the research projects are dealing with how a tram system is useful and efficient in order to re-develop the cities. There are no previous studies of conducting comparison research on urban structure in terms of tram network. This study is characteristic for analyzing the interrelationship between urban structure and urban facilities in terms of tram network by using the morphological analysis. This paper will contribute to help decisions for making/re-making the tram network as a 'package approach'.

\section{The tram type cities}

\subsection{Twenty-four tram type cities in Europe}

In order to understand the relationship between the tram network and public facilities, we then decided to search the tram type city in the twenty-seven countries, which are participating to the European Union. We conducted research on previous studies, documents, books and the Internet [12-15].

We were able to pick up one hundred ninety-one cities of which all have tram and subway/metro. Among these one hundred ninety-one cities, there are one hundred and forty-four cities that do not have subway/metro in the twenty-seven EU countries. We found that there are 144 tram type cities and we were able to extract ninety-one tram type cities in the se west European countries (see Table 1). We found forty-five tram type cities in Germany, fifteen cities in France. The names of the tram type cities in each country are seen in Table 1.

We then analyzed the population of these cities, and picked up thirty-one cities from the ninety-one cities. These thirty-one cities have a population from on hundred thousand to two hundred thousand, because this population size is equivalent to the maximum size large area community [16] (see Table 1 and Figure 1).

\subsection{About the twenty four tram type cities}

In order to analyze the location of the public facilities and the tramway in the cities, we decided to get the city maps of these cities. We were able to get twenty-four city maps. We used thirteen examples from Germany, seven 
examples from France, one example from the United Kingdom, and three examples from Austria [17] (see Table 2). Basic data of the twenty-four cities are seen in Table 2.

Table 1: $\quad$ The names of tram type cities in west European countries (101 cities).

\begin{tabular}{c|l}
\hline Names of the Country & \multicolumn{1}{|c}{ Name of the City (91) } \\
\hline Belgium(2), & Oostende, Ghent, \\
\hline Portugal(3), & Almada, Sintra, Margem Sul, \\
\hline Spain(5), & Sevilla, Tenerife, Vèlez-Màlaga, Murcia, La Coruña, \\
\hline Austria(6), & Innsbruck, Gmunden, Klagenfurt, Graz, Salzburg, Linz, \\
\hline \multirow{3}{*}{ Germany(45) } & $\begin{array}{l}\text { Augsburg, Jena, Weinheim, Würzburg, Woltersdorf, Ulm, Erfurt, Oberhausen, } \\
\text { Kassel, Kreferd, Chemnitz, Gera, Görlitz, Gotha, Cottbus, Saarbrücken, } \\
\text { Schöneiche, Strausberg, Schwerin, Darmstadt, Zwickau, Dessau, Dresden, } \\
\text { Naumburg, Neuss, Nordhausen, BadWildbad, Heidelberg, Heilbronn, Halberstadt, } \\
\text { Halle, Freiburg, Braunschweig, Bremen, Potsdam, Mainz, Magdeburg, Leipzig, } \\
\text { Ludwigshafen, Rostock, Frankfurt am der oder, Brandenburg, Bielefeld, Bad } \\
\text { Schandau, Plauen }\end{array}$ \\
\hline France(15) & $\begin{array}{l}\text { Valenciennes, Orlèans, Caen, Grenoble, Clermont-Ferrand, St-Etienne, } \\
\text { Strasbourg, Nancy, Nantes, Nice, Bordeaux, Mulhouse, Montpellier, Le Mans, } \\
\text { Tirano }\end{array}$ \\
\hline Italy(10) & $\begin{array}{l}\text { Cagliari, Sassari, Soprabolzano, Trieste, Padova, Bolzano, } \\
\text { Malé, Messina, L'Aquila, Rimini, }\end{array}$ \\
\hline The Netherlands(3) & Den Haag, Houten, Utrecht \\
\hline United Kingdom(7) & Croydon, Sheffield, Douglas, Nottingham, Blackpool, Manchester, Wimbledon \\
\hline (Note) The number in '( )’ indicates the number of the cities in each country
\end{tabular}

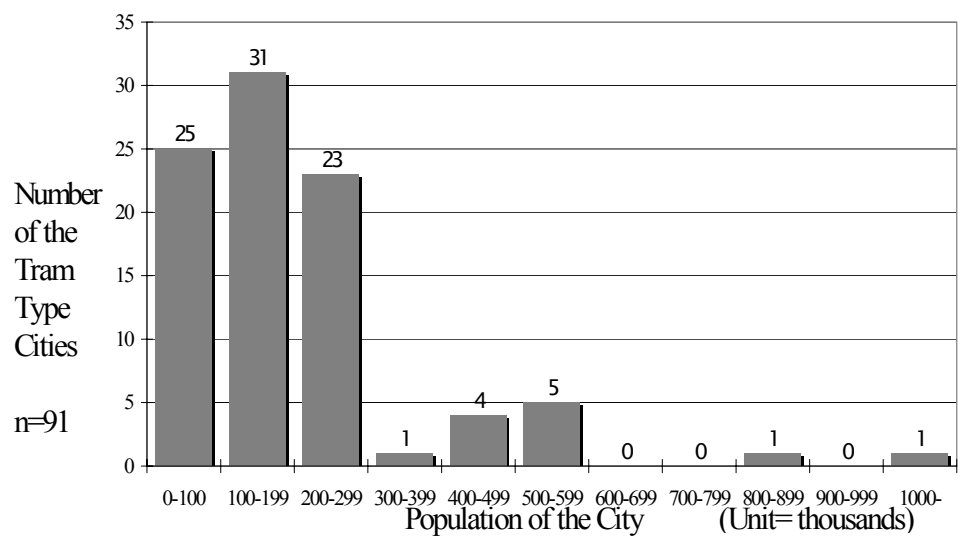

Figure 1: $\quad$ Population and number of the cities in west Europe countries.

\subsection{Analyzing method}

In order to understand urban structure of the tram type cities, first of all, we defined the 'tram stop community area', which is in a circle form. We then 
decided to count the number of the urban facilities in this community area. The diameter of this circle is $600 \mathrm{~m}$, and it has the centre on a tram stop. We were able to refer to the neighbourhood community theory. Yoshitake defined this scale in order to make an adequate community. The size of this neighbourhood community is around $600 \mathrm{~m} \times 600 \mathrm{~m}$ of an urban unit. This size of the community unit is regard as the walking orientated daily-living area [18]. While in order to set up the observation area of the city we defined the 'large community area' in which the population is from on hundred thousand to two hundred thousand. This community size is used in Germany for the political purposes of several cities $[19,20]$. The population size of the tram type cities is the highest in Figure 1. For the urban facilities, we observed the locations of the following facilities; educational facility, religious facility, local government office, hospital/medical facility, park and squares, mills, and pedestrian areas/commercial streets in this paper.

Table 2: $\quad$ City data of the 24 tram type cities.

\begin{tabular}{|c|c|c|c|c|c|c|c|}
\hline \multicolumn{2}{|c|}{$\begin{array}{l}\text { Symbols of the city \& } \\
\text { The Names of the City }\end{array}$} & \multirow{2}{*}{\begin{tabular}{|c|}
$\begin{array}{l}\text { Population } \\
\text { of the city }\end{array}$ \\
102,494 \\
\end{tabular}} & \multirow{2}{*}{\begin{tabular}{|c|}
$\begin{array}{c}\text { City Area } \\
(\mathrm{km} 2)\end{array}$ \\
114.0 \\
\end{tabular}} & \multirow{2}{*}{\begin{tabular}{|c|}
$\begin{array}{c}\text { Number of } \\
\text { the tram } \\
\text { line(s) }\end{array}$ \\
6
\end{tabular}} & \multirow{2}{*}{ 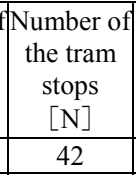 } & \multirow{2}{*}{$\begin{array}{c}\text { Total length } \\
\text { of the } \\
\text { tramway } \\
{[\mathrm{T} \mathrm{Km}]}\end{array}$} & \multirow{2}{*}{$\begin{array}{c}\begin{array}{c}\text { Average } \\
\text { length of the } \\
\text { tram stops } \\
(\mathrm{m})\end{array} \\
512 \\
\end{array}$} \\
\hline D1 & Jena & & & & & & \\
\hline D2 & Würzburg & 134,225 & 87.6 & 5 & 46 & \begin{tabular}{|l|}
19 \\
\end{tabular} & \begin{tabular}{|l|}
422 \\
\end{tabular} \\
\hline D3 & Ulm & 120,925 & 118.7 & 1 & 15 & 6 & 429 \\
\hline D4 & Kassel & 193,518 & 161.0 & 9 & 97 & 47 & 490 \\
\hline D5 & Gera & 102,486 & 151.9 & 3 & 41 & 14 & 350 \\
\hline D6 & Saarbrücken & 180,515 & 167.1 & 1 & 18 & 5 & 265 \\
\hline D7 & Darmstadt & 141,471 & 122.2 & 8 & 68 & 41 & 613 \\
\hline D8 & Neuss & 152,625 & 99.5 & 1 & 10 & $8 *$ & 889 \\
\hline D9 & Heidelberg & 144,634 & 108.8 & 3 & 44 & 21 & 488 \\
\hline D10 & Heilbronn & 121,384 & 99.9 & 1 & 10 & 1.3 & 144 \\
\hline D11 & Potsdam & 150,000 & 187.3 & 6 & 64 & 26 & 413 \\
\hline D12 & Ludwigshafen & 163,560 & 77.7 & 6 & 67 & 30 & 455 \\
\hline D13 & Rostock & 199,097 & 181.4 & 6 & 61 & 22 & 367 \\
\hline F14 & Orléans & 113,126 & 27.5 & 1 & 24 & 18 & 783 \\
\hline F15 & Caen & 113,987 & 25.7 & 2 & 34 & 16 & 476 \\
\hline F16 & Grenoble & 157,900 & 18.1 & 4 & 63 & 19 & 306 \\
\hline F17 & St-Etienne & 175,700 & 80.0 & 1 & 36 & 9 & 257 \\
\hline F18 & Nancy & 105,400 & 15.0 & 1 & 29 & 11 & 393 \\
\hline F19 & Mulhouse & 110,359 & 22.2 & 2 & 22 & 12 & 571 \\
\hline $\mathrm{F} 20$ & Le Mans & 146,105 & 52.8 & 1 & 29 & $15^{*}$ & 536 \\
\hline $\mathrm{U} 21$ & Blackpool & 142,700 & 34.9 & 1 & 19 & 18 & 1000 \\
\hline A22 & Innsbruck & 117,916 & 104.9 & 3 & 38 & 36 & 973 \\
\hline A23 & Salzburg & 150,269 & 65.7 & 1 & 20 & 34 & 1789 \\
\hline \multirow[t]{2}{*}{ A24 } & Linz & 188,968 & 96.1 & 2 & 51 & 15 & 300 \\
\hline & Average & 142,890 & 92.5 & 3.1 & 39.5 & 20.0 & 551 \\
\hline
\end{tabular}

(Note) 1) Average length of the Tram Stops.

2) The total length of the tramlines of Neuss and Le Mans were measured by the author.

3) (Average length of tram stops) $=\mathrm{T} /(\mathrm{N}-1) \times 1000(\mathrm{~m})$

4) The data of the population and city area are from Wikipedia. This research was conducted in June 2008. 


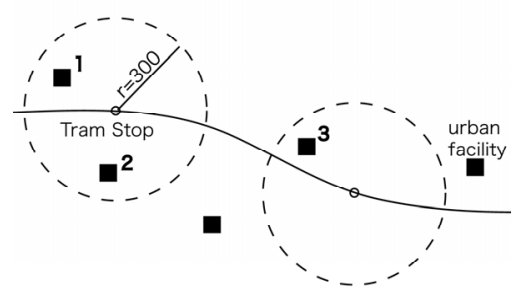

Figure 2: Connectivity analysis Figure 3: model.

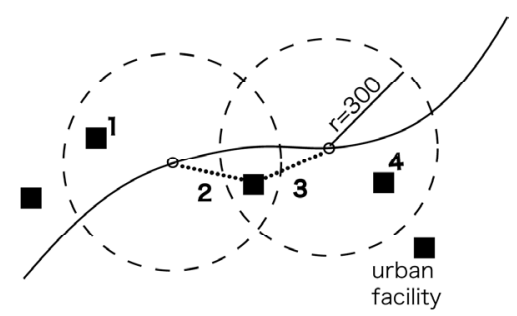

Accessibility analysis model.

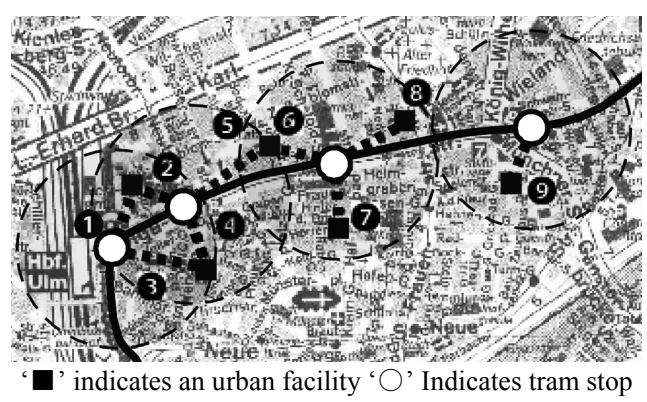

Figure 4: The number of the public facilities in the tram stop community. (This example is from the central area of Ulm.)

Note on Figure 2 and 3:

Figure 2 shows three urban facilities that are in two tram stop community areas. When more than two tram-stops are covering each other, we counted two times for one facility. This is the accessible analysis in this paper. Figure 3 shows four urban facilities that are in two tram-stop community areas.

Secondly we calculated two means to count the number of public facilities in the tram stop community area; 1) One method is to count the real number of the existing public facilities in each tram stop community area. We call this analysis method the 'connectivity analysis method'. By using this method, we are able to understand how many urban facilities are in the tram stop community area. 2) The other method we use in this paper is the 'accessibility analysis method'. We use this method when more than two tram community areas are covering each other's areas, then we have to count more than two times for one urban facility. This means that this public facility is covered by more than two tram stops within a walk-able distance. This method gives us the accessible number of the tram passenger for each urban facility [21].

For example, when we analyze the number of urban facilities along a part of the tram network in Ulm, Germany, there are 6 existing public facilities within 4 tram stop areas (the connectivity analysis), and there are 9 urban facilities in 4 areas (the accessibility analysis) (see Figure 4). 


\section{Public facilities in the tram stop community}

\subsection{Location of the public facilities from the tram stops}

We extracted urban facilities on each city map, and we made $600 \mathrm{~m}$ diameter circles around the tram stops on the map. One example of this analysis is seen on Figure 6 . As the result of connectivity analysis, we found 1374 urban facilities in the tram stop community areas of the twenty-four cities (see Table 3). This is the real number for ten kinds of urban facilities.

Table 3: The real number of urban facilities (by the connectivity analysis).

\begin{tabular}{c|c|c|c|c|c|c|c|c|c|c|c|c}
\hline $\begin{array}{c}\text { Symbols of the city \& The } \\
\text { Names of the City }\end{array}$ & RF & EF & GO & HM & AF & CF & PS & PA & ML & OT & Total \\
\hline D1 & Jena & 5 & 23 & 3 & 6 & 3 & 6 & 2 & 3 & 0 & 0 & 51 \\
\hline D2 & Würzburg & 24 & 17 & 7 & 4 & 3 & 1 & 1 & 2 & 0 & 0 & 59 \\
\hline D3 & Ulm & 11 & 6 & 5 & 1 & 7 & 0 & 1 & 6 & 0 & 0 & 37 \\
\hline D4 & Kassel & 39 & 44 & 12 & 12 & 9 & 7 & 4 & 4 & 1 & 0 & 132 \\
\hline D5 & Gera & 7 & 18 & 2 & 3 & 1 & 3 & 2 & 3 & 0 & 0 & 39 \\
\hline D6 & Saarbrücken & 5 & 9 & 5 & 1 & 1 & 0 & 3 & 4 & 0 & 0 & 28 \\
\hline D7 & Darmstadt & 15 & 20 & 6 & 1 & 4 & 0 & 4 & 1 & 0 & 0 & 51 \\
\hline D8 & Neuss & 3 & 4 & 1 & 1 & 2 & 3 & 0 & 6 & 0 & 0 & 20 \\
\hline D9 & Heidelberg & 33 & 14 & 12 & 6 & 1 & 3 & 2 & 2 & 1 & 0 & 74 \\
\hline D10 & Heilbronn & 4 & 2 & 2 & 0 & 0 & 3 & 1 & 2 & 0 & 0 & 14 \\
\hline D11 & Potsdam & 6 & 13 & 6 & 6 & 5 & 3 & 2 & 1 & 0 & 0 & 42 \\
\hline D12 & Ludwigshafen & 23 & 16 & 10 & 3 & 2 & 4 & 4 & 3 & 1 & 0 & 66 \\
\hline D13 & Rostock & 5 & 45 & 5 & 8 & 4 & 2 & 4 & 3 & 0 & 0 & 76 \\
\hline F14 & Orléans & 8 & 27 & 3 & 2 & 4 & 7 & 4 & 14 & 0 & 0 & 69 \\
\hline F15 & Caen & 11 & 23 & 4 & 1 & 0 & 3 & 2 & 1 & 0 & 0 & 45 \\
\hline F16 & Grenoble & 21 & 69 & 11 & 7 & 23 & 18 & 22 & 26 & 0 & 1 & 198 \\
\hline F17 & St-Etienne & 11 & 12 & 1 & 6 & 0 & 2 & 2 & 5 & 1 & 0 & 40 \\
\hline F18 & Nancy & 10 & 17 & 4 & 6 & 2 & 4 & 5 & 10 & 0 & 1 & 59 \\
\hline F19 & Mulhouse & 13 & 23 & 5 & 0 & 5 & 8 & 9 & 6 & 0 & 1 & 70 \\
\hline F20 & Le Mans & 10 & 18 & 2 & 2 & 1 & 0 & 2 & 8 & 0 & 2 & 45 \\
\hline U21 & Blackpool & 12 & 1 & 0 & 0 & 1 & 3 & 5 & 3 & 1 & 0 & 26 \\
\hline A22 & Innsbruck & 19 & 7 & 5 & 2 & 2 & 1 & 2 & 3 & 0 & 0 & 41 \\
\hline A23 & Salzburg & 2 & 5 & 2 & 0 & 1 & 0 & 0 & 0 & 0 & 0 & 10 \\
\hline A24 & Linz & 20 & 33 & 8 & 2 & 3 & 7 & 3 & 3 & 0 & 3 & 82 \\
\hline & Total Number & 317 & 466 & 121 & 80 & 84 & 88 & 86 & 119 & 5 & 8 & 1374 \\
\hline Not & & & & & & & & &
\end{tabular}

(Note)

PA: Pedestrian Area, RF: Religious Facility, EF: Educational Facility.

GO: Government Office, HM: Hospital / Medical Facility, ML: Mills.

AF: Amusement Facility, CF: Cultural Facilities, PS: Park \& Square.

OT: Other Urban Facilities.

The average number of urban facilities for a city is fifty-seven. The maximum number of urban facilities in total is seen at the city of Grenoble (198 facilities). Next comes Kassel (132 facilities). These two cities have a more intimate connection with Hospitals or medical facilities from the tram stops, when compared with other cities. Grenoble is a city in which many kinds of urban facilities are located close to the tramways. There are many amusement facilities and parks and squares to be seen in the tram stop community areas of Grenoble. 

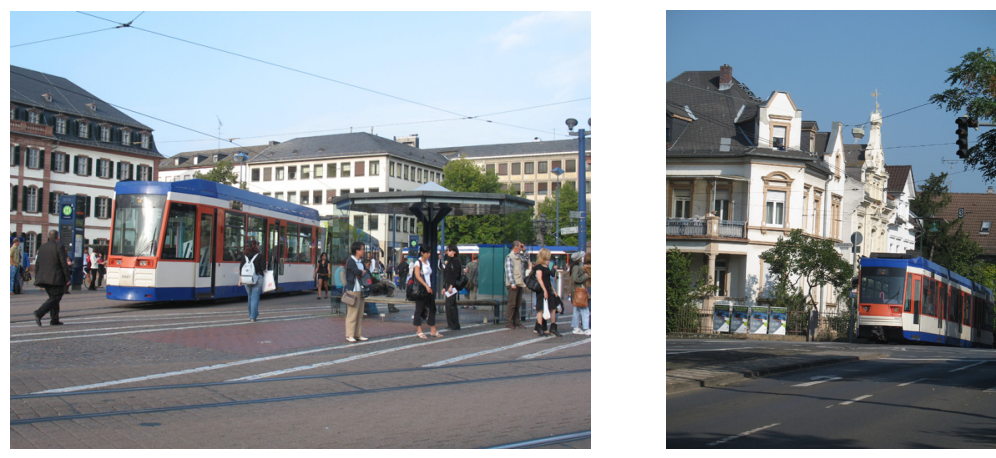

Figure 5: Photos of the tram and urban space in Darmstadt. Photos by the author.

We found that certain kinds of urban facilities are located near the tramway in Kassel. When we conducted the accessibility analysis method, we were able to define 2197 urban facilities in the tram stop community areas (see Table 4).

When we consider Table 4, the most accessible urban facility is educational facilities in the total number (667 facilities, 30\%), next comes religious facilities (495 facilities, 23\%), and then comes, pedestrian areas (307 streets, 14\%). Generally, we are able to affirm that there are many educational facilities, religious facilities and pedestrian areas located near the tram stops in the twentyfour cities. We are able to say that the passengers of the tram find it easy to approach these three urban facilities from the tram stops.

Comparing the accessibility and connectivity of Kassel and Grenoble, Grenoble has a certain number of urban facilities, but the accessibility in this city is not high, when considering the accessibility of Kassel. Kassel does not have many facilities, but this city shows a higher accessibility (compare Table 3 and Table 4). Thus, we decided to conduct the analysis of the ratio of accessibility against connectivity as the next subject.

\subsection{Ratio of accessibility}

The next subject is to understand the ratio of accessibility of each public facility in each city. In order to understand ratio of accessibility against connectivity, we used the following numerical formula in Tables 3 and 4 (see 'A') [22].

$$
\text { Ratio of accessibility }(\text { Table } 5)=(\text { Table } 4) \div(\text { Table } 3)
$$

Since Table 5 is the result of calculation method 'A', we are able to determine which public facility is closer to the tram stops of in the 24 tram type cities. Higher ratios of accessibility against connectivity help us to compare the condition of each public facility, in relation with the tram networks of the other tram type cities.

When we focus on educational facilities, for which is the most connective and accessible urban facility (refer to Table 3) from the tram stop, the city of 
Innsbruck (Austria) shows 2.3 points. This means that you are able to reach at least two educational facilities from any tram stop in tram stop community areas.

When we focus on pedestrian areas, Würzburg (Germany) has 6.5 points, Potsdam has 5.0 points, Jena, Darmstadt, Rostock (these cities are in Germany) and St-Etienne (France) have 4.0 points. Among these tram type cities, it turned out that Würzburg and these six cities have a more intimate relationship between pedestrian areas and tram stops. In the 24 cities, Innsbruck has relatively high points. In particular this city has a closer interrelation between tram stops and the following four urban facilities; educational facilities, hospitals/medical facilities, squares \& parks, and pedestrian areas. This city has good conditions for the tram passenger to reach and approach many kinds of public facilities by walking.

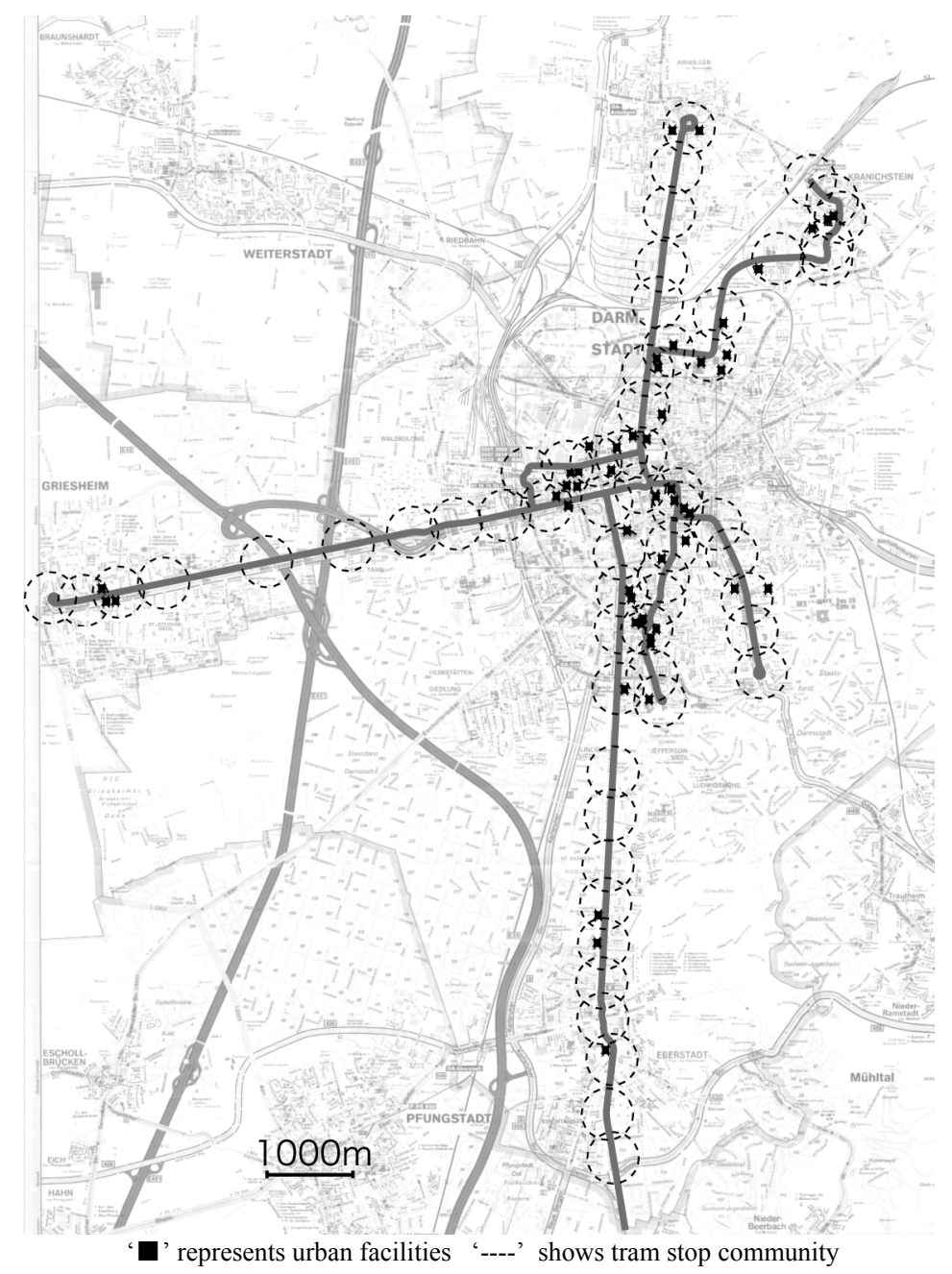

Figure 6: An example of tram network and urban facilities (Darmstadt). 
Table 4: The number of accessible urban facilities (by the accessibility analysis).

\begin{tabular}{|c|c|c|c|c|c|c|c|c|c|c|c|c|}
\hline \multicolumn{2}{|c|}{$\begin{array}{c}\text { Symbols of the city \& The } \\
\text { Names of the City }\end{array}$} & \multirow{2}{*}{$\begin{array}{c}\text { RF } \\
8\end{array}$} & \multirow{2}{*}{$\frac{E F}{37}$} & GO & $\mathrm{HM}$ & $\mathrm{AF}$ & $\mathrm{CF}$ & PS & PA & ML & OT & Total \\
\hline D1 & Jena & & & 8 & 10 & 3 & 9 & 3 & 12 & 0 & 0 & 90 \\
\hline D2 & Würzburg & 53 & 34 & 14 & 9 & 4 & 2 & 1 & 13 & 0 & 0 & 130 \\
\hline D3 & Ulm & 14 & 8 & 6 & 1 & 11 & 0 & 2 & 14 & 0 & 0 & 56 \\
\hline D4 & Kassel & 64 & 72 & 20 & 23 & 15 & 11 & 8 & 15 & 2 & 0 & 230 \\
\hline D5 & Gera & 12 & 27 & 2 & 3 & 1 & 4 & 2 & 10 & 0 & 0 & 61 \\
\hline D6 & Saarbrücken & 5 & 10 & 6 & 1 & 2 & 0 & 3 & 9 & 0 & 0 & 36 \\
\hline D7 & Darmstadt & 26 & 33 & 9 & 2 & 4 & 0 & 10 & 4 & 0 & 0 & 88 \\
\hline D8 & Neuss & 4 & 5 & 2 & 1 & 2 & 3 & 0 & 15 & 0 & 0 & 32 \\
\hline D9 & Heidelberg & 55 & 23 & 30 & 11 & 2 & 6 & 3 & 6 & 1 & 0 & 137 \\
\hline D10 & Heilbronn & 5 & 2 & 2 & 0 & 0 & 3 & 1 & 5 & 0 & 0 & 18 \\
\hline D11 & Potsdam & 11 & 19 & 8 & 8 & 5 & 4 & 2 & 5 & 0 & 0 & 62 \\
\hline D12 & Ludwigshafen & 30 & 25 & 18 & 4 & 3 & 5 & 7 & 9 & 3 & 0 & 104 \\
\hline D13 & Rostock & 10 & 48 & 8 & 12 & 4 & 3 & 5 & 12 & 0 & 0 & 102 \\
\hline F14 & Orléans & 8 & 31 & 4 & 2 & 4 & 6 & 5 & 26 & 0 & 0 & 86 \\
\hline F15 & Caen & 15 & 32 & 4 & 1 & 0 & 7 & 6 & 3 & 0 & 0 & 68 \\
\hline F16 & Grenoble & 29 & 78 & 17 & 8 & 27 & 24 & 30 & 49 & 0 & 2 & 264 \\
\hline F17 & St-Etienne & 21 & 25 & 3 & 7 & 0 & 7 & 5 & 11 & 3 & 0 & 82 \\
\hline F18 & Nancy & 19 & 29 & 8 & 7 & 3 & 7 & 7 & 27 & 0 & 1 & 108 \\
\hline F19 & Mulhouse & 14 & 26 & 6 & 0 & 6 & 11 & 17 & 13 & 0 & 2 & 95 \\
\hline F20 & Le Mans & 15 & 19 & 3 & 2 & 1 & 0 & 2 & 19 & 0 & 2 & 63 \\
\hline U21 & Blackpool & 14 & 1 & 0 & 0 & 2 & 6 & 11 & 8 & 1 & 0 & 43 \\
\hline $\mathrm{A} 22$ & Innsbruck & 25 & 16 & 12 & 7 & 3 & 2 & 4 & 12 & 0 & 0 & 81 \\
\hline A23 & Salzburg & 3 & 8 & 2 & 0 & 1 & 0 & 0 & 0 & 0 & 0 & 14 \\
\hline A24 & Linz & 35 & 59 & 13 & 5 & 8 & 11 & 3 & 10 & 0 & 3 & 147 \\
\hline & otal Number & 495 & 667 & 205 & 124 & 111 & 131 & 137 & 307 & 10 & 10 & 2197 \\
\hline
\end{tabular}

(Note) PA: Pedestrian Area, RF: Religious Facility, EF: Educational Facility.

GO: Government Office, HM: Hospital / Medical Facility, AF: Amusement Facility.

CF: Cultural Facilities, PS: Park \& Square, ML: Mills, OT: Other Urban Facilities.

\section{Tram network and pedestrian areas}

\subsection{Location of pedestrian areas and public facilities}

The next subject is about the location of pedestrian areas in the 'large community area'. We aim to understand how many pedestrian areas there are in the whole city. We conducted a count for how many pedestrian areas/streets there are in the whole city. As the result, we are able to define one hundred eighty pedestrian areas in the twenty-four cities (see Table 6).

While we found that there are one hundred eighty pedestrian areas in the tram stop community areas of twenty-three cities (Salzburg does not have a pedestrian area, see Table 3). This result tells us that sixty-six percent of the pedestrian areas are located in the tram stop community areas as the whole (see Table 6).

Therefore, we then decided to consider pedestrian usability from the pedestrian areas to public facilities. We made Table 7 from Table 6. In other words, we aimed to calculate the percentage of how many urban facilities are connected with the pedestrian areas, so we did following calculation.

$$
\text { Ratio of pedestrian usability }(\text { Table } 7)=(\text { Table } 3) \div(\text { Table } 6) \times 100
$$


As the result of the calculation ' $\mathrm{B}$ ', we got Table 7. This table shows us the characteristics of each city in terms of pedestrian usability between pedestrian areas and public facilities. When this usability of an urban facility is getting closer to one hundred percent it means that ability of a pedestrian to reach the public facility from the pedestrian area is easier. Thus, we are able to regard the percentage of pedestrian usability as the accessibility point for the pedestrian of each city. We call this the 'pedestrian accessibility point'.

Table 5: $\quad$ Ratio of accessibility of the cities.

\begin{tabular}{|c|c|c|c|c|c|c|c|c|c|c|c|}
\hline \multicolumn{2}{|c|}{$\begin{array}{c}\text { Symbols of the city \& } \\
\text { Names of the City }\end{array}$} & \multirow{2}{*}{$\begin{array}{l}\mathrm{RF} \\
1.6\end{array}$} & \multirow{2}{*}{$\begin{array}{l}\text { EF } \\
1.6\end{array}$} & \multirow{2}{*}{$\frac{\mathrm{GO}}{2.7}$} & \multirow{2}{*}{$\begin{array}{c}\mathrm{HM} \\
1.7\end{array}$} & \multirow{2}{*}{$\begin{array}{c}\mathrm{AF} \\
1\end{array}$} & \multirow{2}{*}{$\begin{array}{l}\mathrm{CF} \\
1.5\end{array}$} & \multirow{2}{*}{$\begin{array}{l}\text { PS } \\
1.5\end{array}$} & \multirow{2}{*}{$\begin{array}{c}\text { PA } \\
4\end{array}$} & \multirow[t]{2}{*}{ ML } & \multirow[t]{2}{*}{ OT } \\
\hline D1 & Jena & & & & & & & & & & \\
\hline D2 & Würzburg & 2.2 & 2 & 2 & 2.3 & 1.3 & 2 & 1 & 6.5 & & \\
\hline D3 & Ulm & 1.3 & 1.3 & 1.2 & 1 & 1.6 & & 2 & 2.3 & & \\
\hline D4 & Kassel & 1.6 & 1.6 & 1.7 & 1.9 & 1.7 & 1.6 & 2 & 3.8 & 2 & \\
\hline D5 & Gera & 1.7 & 1.5 & 1 & 1 & 1 & 1.3 & 1 & 3.3 & & \\
\hline D6 & Saarbrücken & 1 & 1.1 & 1.2 & 1 & 2 & & 1 & 2.3 & & \\
\hline D7 & Darmstadt & 1.7 & 1.7 & 1.5 & 2 & 1 & & 2.5 & 4 & & \\
\hline D8 & Neuss & 1.3 & 1.3 & 2 & 1 & 1 & 1 & & 2.5 & & \\
\hline D9 & Heidelberg & 1.7 & 1.6 & 2.5 & 1.8 & 2 & 3 & 2 & 2 & 1 & \\
\hline D10 & Heilbronn & 1.3 & 1 & 1 & & & 1 & 1 & 2.5 & & \\
\hline D11 & Potsdam & 1.8 & 1.5 & 1.3 & 1.3 & 1 & 1.3 & 1 & 5 & & \\
\hline D12 & Ludwigshafen & 1.3 & 1.6 & 1.8 & 1.3 & 1.5 & 1.3 & 1.8 & 3 & 3 & \\
\hline D13 & Rostock & 2 & 1.1 & 1.6 & 1.5 & 1 & 1.5 & 1.3 & 4 & & \\
\hline F14 & Orléans & 1 & 1.1 & 1.3 & 1 & 1 & 0.9 & 1.3 & 1.9 & & \\
\hline F15 & Caen & 1.4 & 1.4 & 1 & 1 & & 2.3 & 3 & 3 & & \\
\hline F16 & Grenoble & 1.4 & 1.1 & 1.5 & 1.1 & 1.2 & 1.3 & 1.4 & 1.9 & & 2 \\
\hline F17 & St-Etienne & 1.6 & 1.6 & 2.7 & 1.7 & 1 & 1.5 & 1.5 & 4 & & \\
\hline F18 & Nancy & 2.2 & 2 & 2 & 2.3 & 1.3 & 2 & 1 & 6.5 & & 1 \\
\hline F19 & Mulhouse & 1.3 & 1.3 & 1.2 & 1 & 1.6 & & 2 & 2.3 & 2 & 2 \\
\hline F20 & Le Mans & 1.6 & 1.6 & 1.7 & 1.9 & 1.7 & 1.6 & 2 & 3.8 & & 1 \\
\hline U21 & Blackpool & 1.7 & 1.5 & 1 & 1 & 1 & 1.3 & 1 & 3.3 & & \\
\hline A22 & Innsbruck & 1 & 1.1 & 1.2 & 1 & 2 & & 1 & 2.3 & & \\
\hline A23 & Salzburg & 1.7 & 1.7 & 1.5 & 2 & 1 & & 2.5 & 4 & & \\
\hline A24 & Linz & 1.3 & 1.3 & 2 & 1 & 1 & 1 & & 2.5 & 1 & 1 \\
\hline
\end{tabular}

(Note) PA: Pedestrian Area, RF: Religious Facility, EF: Educational Facility.

GO: Government Office, HM: Hospital / Medical Facility, AF: Amusement Facility.

CF: Cultural Facilities, P\&S: Park \& Square, ML: Mills, OT: Other Urban Facilities.

\subsection{Pedestrian accessibility point}

Looking at Table 6, we are able to pick up several urban facilities, of which the pedestrian accessibility points are at one hundred. There are thirteen cities that have one hundred points for religious facility, ten cities have one hundred points for government office and one hundred points for cultural facility, eight cities have one hundred points for educational facility, four cities have one hundred points for park \& square, and two cities have one hundred points for hospital/medical facility and amusement facility (see Table 7).

For Table 4, the highest facility was educational in number, while religious facilities were mostly located along the pedestrian areas in the tram stop community areas. It is usually easier and more accessible for pedestrians to reach 
religious facilities than to reach educational facilities via pedestrian areas. According to Table 7, we are able to evaluate tram type of cities in terms of pedestrian mobility by using the tram network. Kassel and Innsbruck got five hundred points. Jena, Darmstadt, Neuss and Linz got four hundred points. We are able to affirm that these cities have intimate relationship between the tram network and urban facilities. When we see these six cities in Table 7 , it turned out that these 6 cities have a large number of educational and religious facilities. Thus, we are able to affirm that these six cities have a highly pedestrianorientated urban structure for the citizens to use the tram for their daily life.

Table 6: The number of public facilities along the pedestrian areas in the large community.

\begin{tabular}{|c|c|c|c|c|c|c|c|c|c|c|c|}
\hline \multicolumn{2}{|c|}{$\begin{array}{l}\text { Symbols of the city \& } \\
\text { The Names of the City }\end{array}$} & \multirow{2}{*}{$\frac{\mathrm{PA}}{3}$} & \multirow{2}{*}{$\frac{\mathrm{RF}}{2}$} & \multirow{2}{*}{$\frac{E F}{2}$} & \multirow{2}{*}{$\frac{\mathrm{GO}}{1}$} & \multirow{2}{*}{$\frac{\mathrm{HM}}{0}$} & \multirow{2}{*}{$\frac{\mathrm{AF}}{0}$} & \multirow[t]{2}{*}{$\mathrm{CF}$} & \multirow{2}{*}{$\frac{\mathrm{PS}}{0}$} & Total & TM \\
\hline D1 & Jena & & & & & & & & & \begin{tabular}{|l|}
6 \\
\end{tabular} & $\mathrm{~N}$ \\
\hline $\mathrm{D} 2$ & Würzburg & 2 & 5 & 0 & 1 & 1 & 0 & 0 & 0 & 7 & $\mathrm{Y}$ \\
\hline D3 & Ulm & 7 & 2 & 1 & 1 & 0 & 0 & 1 & 0 & 5 & $\mathrm{Y}$ \\
\hline D4 & Kassel & 4 & 2 & 2 & 1 & 0 & 1 & 0 & 1 & 7 & $\mathrm{Y}$ \\
\hline D5 & Gera & 3 & 2 & 0 & 1 & 0 & 0 & 1 & 0 & 4 & $\mathrm{~N}$ \\
\hline D6 & Saarbrücken & 7 & 4 & 1 & 1 & 0 & 0 & 0 & 0 & 6 & $\mathrm{~N}$ \\
\hline D7 & Darmstadt & 1 & 3 & 1 & 2 & 1 & 0 & 0 & 0 & 7 & $\mathrm{Y}$ \\
\hline D8 & Neuss & 6 & 1 & 1 & 1 & 0 & 1 & 0 & 0 & 4 & $\mathrm{Y}$ \\
\hline D9 & Heidelberg & 5 & 6 & 8 & 2 & 1 & 1 & 4 & 0 & 22 & $\mathrm{~N}$ \\
\hline D10 & Heilbronn & 3 & 2 & 0 & 2 & 0 & 0 & 2 & 0 & 6 & $\mathrm{Y}$ \\
\hline D11 & Potsdam & 1 & 0 & 0 & 0 & 0 & 0 & 0 & 0 & 0 & $\mathrm{~N}$ \\
\hline D12 & Ludwigshafen & 6 & 3 & 2 & 4 & 0 & 0 & 6 & 0 & 15 & $\mathrm{~N}$ \\
\hline D13 & Rostock & 5 & 2 & 1 & 0 & 0 & 0 & 1 & 0 & 4 & $\mathrm{~N}$ \\
\hline F14 & Orléans & 19 & 2 & 2 & 3 & 1 & 2 & 1 & 1 & 12 & $\mathrm{Y}$ \\
\hline F15 & Caen & 1 & 0 & 0 & 0 & 0 & 0 & 0 & 0 & 0 & $\mathrm{~N}$ \\
\hline F16 & Grenoble & 41 & 4 & 22 & 6 & 0 & 1 & 4 & 6 & 43 & $\mathrm{Y}$ \\
\hline F17 & St-Etienne & 7 & 3 & 0 & 0 & 0 & 0 & 1 & 0 & 4 & $\mathrm{Y}$ \\
\hline F18 & Nancy & 23 & 3 & 0 & 2 & 0 & 0 & 3 & 4 & 12 & $\mathrm{Y}$ \\
\hline F19 & Mulhouse & 12 & 1 & 1 & 0 & 0 & 0 & 1 & 0 & 3 & $\mathrm{~N}$ \\
\hline F20 & Le Mans & 11 & 0 & 0 & 0 & 0 & 0 & 2 & 1 & 3 & $\mathrm{~N}$ \\
\hline U21 & Blackpool & 3 & 1 & 0 & 0 & 0 & 0 & 0 & 0 & 1 & $\mathrm{~N}$ \\
\hline A22 & Innsbruck & 3 & 2 & 2 & 9 & 0 & 0 & 1 & 1 & 15 & $\mathrm{Y}$ \\
\hline A23 & Salzburg & 4 & 10 & 5 & 3 & 1 & 0 & 1 & 6 & 26 & $\mathrm{~N}$ \\
\hline A24 & Linz & 3 & 4 & 3 & 1 & 0 & 0 & 2 & 0 & 10 & $\mathrm{Y}$ \\
\hline \multicolumn{2}{|c|}{ Total Number } & 180 & 64 & 54 & 41 & 5 & 6 & 32 & 20 & 222 & \\
\hline & Average & 7.5 & 2.7 & 2.3 & 1.7 & 0.2 & 0.3 & 1.3 & 0.8 & 9.3 & \\
\hline
\end{tabular}

(Note) PA: Pedestrian Area, RF: Religious Facility, EF: Educational Facility.

GO: Government Office, HM: Hospital / Medical Facility, AF: Amusement Facility.

CF: Cultural Facilities, PS: Park \& Square, ML: Mills, OT: Other Urban Facilities.

TM: When we have transit mall, we put ' $\mathrm{Y}$ ', we do not see any transit mall we typed 'N'.

\section{The structure of the tram type city}

\subsection{Category of the cities}

In order to make groups of the tram type cites in terms of the inter-relationship between the tram stops and urban structure, we collected percentage data of each 
urban facility for each city, and made Figure 7 from Table 3. Then, in order to conduct the calculation, we added the number of tramlines and the number of tram stops (see Table 1). We made a cluster analysis by using the Ward method, and made two dendrograms from Tables 2 and 3 (see Figure 8 and 9) [23].

Table 7: Pedestrian accessibility point.

\begin{tabular}{|c|c|c|c|c|c|c|c|c|c|c|}
\hline \multicolumn{2}{|c|}{$\begin{array}{c}\text { Symbols of the city \& } \text { The } \\
\text { Names of the City }\end{array}$} & \multirow{2}{*}{$\frac{\text { PA }}{100}$} & \multirow{2}{*}{$\begin{array}{l}\text { RF } \\
100\end{array}$} & \multirow{2}{*}{$\begin{array}{c}\mathrm{EF} \\
100\end{array}$} & \multirow{2}{*}{$\frac{\mathrm{GO}}{100}$} & \multirow[t]{2}{*}{ HM } & \multirow[t]{2}{*}{$\mathrm{AF}$} & \multirow{2}{*}{$\frac{\mathrm{CF}}{100}$} & \multirow[t]{2}{*}{ PS } & \multirow{2}{*}{$\frac{\text { Total Point }}{400}$} \\
\hline D1 & Jena & & & & & & & & & \\
\hline D2 & Würzburg & 100 & 100 & & 100 & 100 & & & & 300 \\
\hline D3 & Ulm & 86 & 50 & 100 & 100 & & & 100 & & 350 \\
\hline D4 & Kassel & 100 & 100 & 100 & 100 & & 100 & & 100 & 500 \\
\hline D5 & Gera & 100 & 100 & & 100 & & & 100 & & 300 \\
\hline D6 & Saarbrücken & 57 & 25 & & 100 & & & & & 125 \\
\hline D7 & Darmstadt & 100 & 100 & 100 & 100 & 100 & & & & 400 \\
\hline D8 & Neuss & 100 & 100 & 100 & 100 & & 100 & & & 400 \\
\hline D9 & Heidelberg & 40 & 17 & & & & & & & 17 \\
\hline D10 & Heilbronn & 67 & 100 & & 50 & & & 100 & & 250 \\
\hline D11 & Potsdam & 100 & & & & & & & & 0 \\
\hline D12 & Ludwigshafen & 50 & 33 & & 25 & & & 17 & & 75 \\
\hline D13 & Rostock & 60 & 100 & 100 & & & & 100 & & 300 \\
\hline F14 & Orléans & 74 & 100 & 50 & 67 & & & 100 & 100 & 417 \\
\hline F15 & Caen & 100 & & & & & & & & 0 \\
\hline F16 & Grenoble & 63 & 75 & 41 & 50 & & & 75 & 17 & 258 \\
\hline F17 & St-Etienne & 71 & 67 & & & & & & & 67 \\
\hline F18 & Nancy & 43 & 67 & & 50 & & & & 25 & 142 \\
\hline F19 & Mulhouse & 50 & 100 & & & & & 100 & & 200 \\
\hline F20 & Le Mans & 73 & & & & & & 100 & 100 & 200 \\
\hline U21 & Blackpool & 100 & 100 & & & & & & & 100 \\
\hline $\mathrm{A} 22$ & Innsbruck & 100 & 100 & 100 & 100 & & & 100 & 100 & 500 \\
\hline A23 & Salzburg & & & & & & & & & \\
\hline A24 & $\operatorname{Linz}$ & 100 & 100 & 100 & 100 & & & 100 & & 400 \\
\hline \multicolumn{2}{|c|}{$\begin{array}{l}\text { The number of cities that the } \\
\text { pedestrian accessible point is } \\
100\end{array}$} & 11 & 13 & 8 & 10 & 2 & 2 & 10 & 4 & \\
\hline \multicolumn{2}{|c|}{$\begin{array}{l}\text { The number of cities that the } \\
\text { pedestrian accessible is from } \\
50 \text { to } 99\end{array}$} & 10 & 4 & 1 & 4 & 0 & 0 & 1 & 0 & \\
\hline \multicolumn{2}{|c|}{$\begin{array}{l}\text { The number of cities that the } \\
\text { pedestrian accessible point is } \\
\text { below } 50\end{array}$} & 2 & 3 & 1 & 1 & 0 & 0 & 1 & 2 & \\
\hline
\end{tabular}

(Note) PA: Pedestrian Area, RF: Religious Facility, EF: Educational Facility.

GO: Government Office, HM: Hospital / Medical Facility, AF: Amusement Facility.

CF: Cultural Facilities, PS: Park \& Square, ML: Mills, OT: Other Urban Facilities.

\subsection{The urban facilities for tram stops}

According to Figure 9, we are able to form five city groups by using connectivity analysis (mainly from Table 3). We are able to divide twenty-four cities into two larger groups; Group-X and Group-Y, then we divided these into five categories; $\mathrm{A} 1, \mathrm{~A} 2, \mathrm{~A} 3, \mathrm{~B} 1, \mathrm{~B} 2$.

The difference between Groups- $\mathrm{X}$ and Groups- $\mathrm{Y}$ is whether the connectivity to educational facilities is more connective than to religious facilities. Groups- $X$ is orientated to connect to educational facilities rather than religious facilities (see Table 8). 


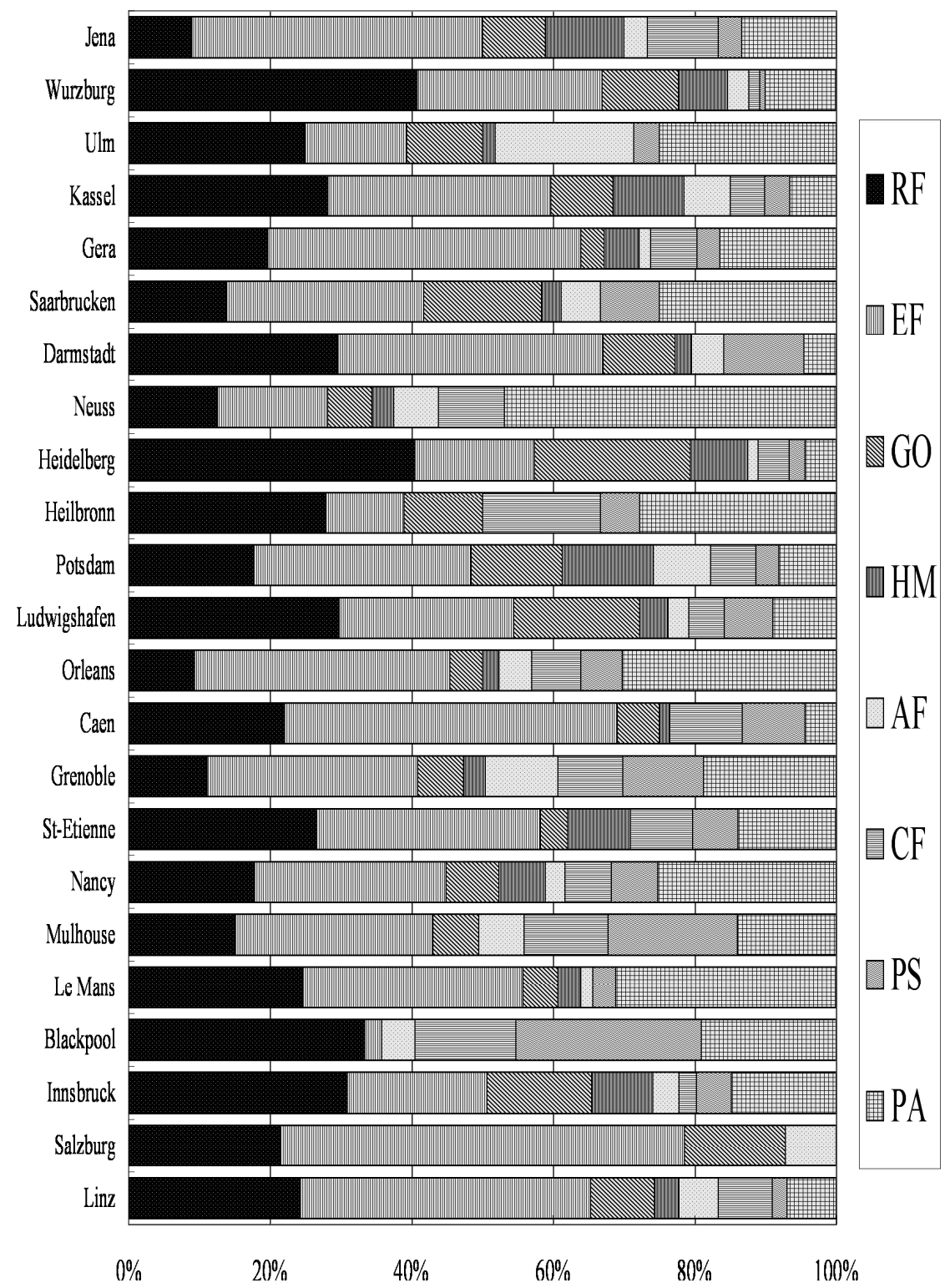

RF: Religious Facility, EF: Educational Facility, GO: Government Office.

HM: Hospital / Medical Facility, AF: Amusement Facility, CF: Cultural Facilities.

PS: Park and Square.

Figure 7: Percentage of the connectivity analysis of the urban facilities.

Concerning to the larger Group-X, Group-A1 includes five cities in which the tram networks are more connective to the educational facilities than to religious 
facilities. Group-A2 includes eight cities in which the tram networks are more connective to the parks and squares than other urban facilities, excluding both educational facilities and religious facilities. Most of the cities in this group are in France, so Group-A2 could be called the French type urban structure. GroupA3 includes one of the cities in which the tram network is more connective to the government offices than other urban facilities, excluding both educational facilities and religious facilities.

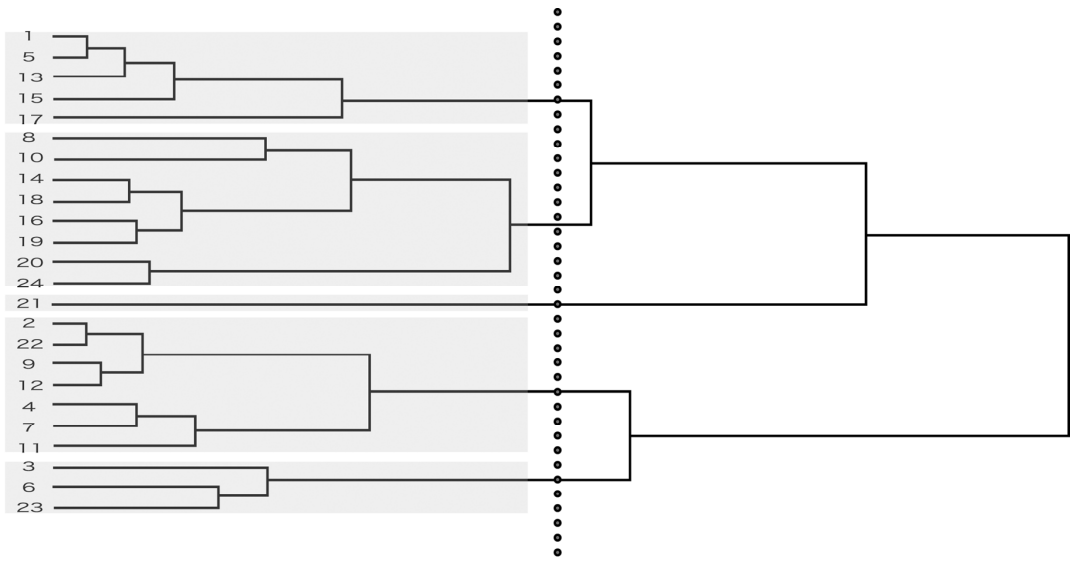

Country identification symbols $(\mathrm{G}, \mathrm{F}, \mathrm{U}$, and $\mathrm{A})$ on the city name are omitted in this graph

Figure 8: Dendrogram of connectivity analysis (from Table 3).

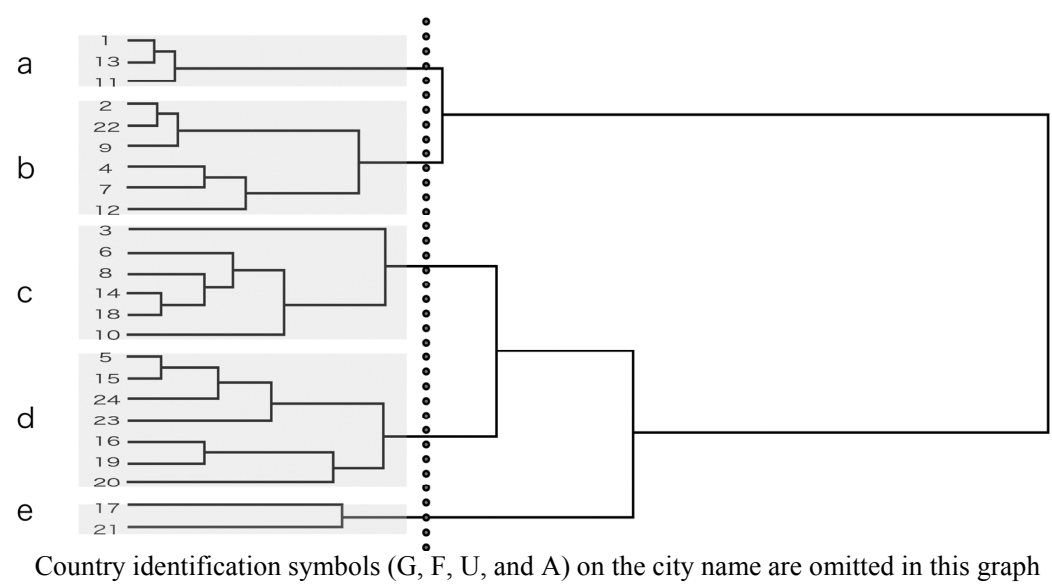

Figure 9: Dendrograms of accessibility analysis (from Table 4).

Concerning to the larger Group-Y, Group-B1 includes one city in which the tram network is more connective to parks and squares than other urban facilities. The name of this city is Blackpool, which is a famous holiday town, so they have a good connection with the parks and squares. Group-B2 includes the seven 
cities in which the tram networks are connective to governmental offices, excluding both religious facilities and educational facilities. Most of the cities are in Germany, so we call Group-B2 type connectivity the German type of urban structure.

Table 8: $\quad$ Groups of the tram type cities.

\begin{tabular}{|c|c|c|c|c|c|}
\hline & & $\begin{array}{l}\text { Connectivity } \\
\text { Analysis }\end{array}$ & & $\begin{array}{l}\text { Accessibility } \\
\text { Analysis }\end{array}$ & The Names of the City \\
\hline \multirow{6}{*}{$\mathrm{X}$} & \multirow{3}{*}{$\begin{array}{l}\text { A1 } \\
(10)\end{array}$} & \multirow{3}{*}{$\mathrm{EF}>\mathrm{RF}$} & 'a & $\mathrm{EF}$ & Jena, Rostock \\
\hline & & & b & $\mathrm{EF}>\mathrm{RF}>\mathrm{PA}$ & Gera, Caen \\
\hline & & & ‘e & $\mathrm{RF}>\mathrm{EF}>\mathrm{PA}>\mathrm{PS}$ & St-Etienne \\
\hline & \multirow[b]{2}{*}{$\begin{array}{l}\text { A2 } \\
(8)\end{array}$} & \multirow[b]{2}{*}{$\mathrm{EF}>\mathrm{RF}>\mathrm{PA}$} & 'c & $\mathrm{PA}>\mathrm{EF}>\mathrm{RF}$ & Neuss, Heilbronn, Orléans, Nancy \\
\hline & & & 'd & $\mathrm{EF}>\mathrm{RF}>\mathrm{PA}$ & $\begin{array}{l}\text { Grenoble, Mulhouse, Le Mans, } \\
\text { Linz }\end{array}$ \\
\hline & $\mathrm{A} 3(3)$ & $\mathrm{EF}>\mathrm{RF}>\mathrm{GO}$ & "c & $\mathrm{PA}>\mathrm{EF}>\mathrm{RF}$ & Ulm, Saarbrücken, Salzburg \\
\hline \multirow{3}{*}{$\mathrm{Y}$} & B1(1) & $\mathrm{RF}>\mathrm{PS}$ & ¿e & $\mathrm{RF}>\mathrm{EF}>\mathrm{PA}>\mathrm{PS}$ & Blackpool \\
\hline & \multirow[b]{2}{*}{$\begin{array}{l}\mathrm{B} 2 \\
(7)\end{array}$} & \multirow[b]{2}{*}{$\mathrm{RF}>\mathrm{EF}>\mathrm{GO}$} & 'a & EF & Potsdam \\
\hline & & & 'b & $\mathrm{RF}>\mathrm{EF}>\mathrm{GO}$ & $\begin{array}{l}\text { Würzburg, Kassel, Darmstadt, } \\
\text { Heidelberg, Ludwigshafen, } \\
\text { Innsbruck }\end{array}$ \\
\hline
\end{tabular}

(Note) PA: Pedestrian Area, RF: Religious Facility, EF: Educational Facility.

GO: Government Office, HM: Hospital / Medical Facility, AF: Amusement Facility.

CF: Cultural Facilities, PS: Park \& Square, ML: Mills, OT: Other Urban Facilities.

The number in ' $($ )' means the number of the city in each group.

$\alpha>\beta$ in Table 8 mean $\alpha$ is more accessible/connective than $\beta$.

On the other hand we see in Figure 10 that we are able to divide the twentyfour cities into five groups ( $a, b, c, d$, and e). Then we compare the results between the connectivity analysis and accessibility analysis, most of the cities have a similar connectivity and accessibility, but it turned out that Group-c does not reflect this connectivity analysis. Neuss, Heilbronn, Orléans, and Nancy have a stronger accessibility to parks and squares than to educational and religious facilities. Ulm, Saarbrücken, Salzburg are the same. Thus, the location of public facilities does not reflect the accessibility at these cities. We are able to say these seven cities are more orientated around the parks and squares than the other cities in terms of accessibility

\section{Tram, connecting public spaces}

As the result of this research we came to following conclusions; 1) through morphological analysis on the tram network and urban facilities, we determined several characteristics of the tram type cities. It became clear that there are two categories of tram type cities. One is the German type and the other is the French type. German type cities include government offices into the tram networks. While French type cities includes pedestrian areas. 2) Generally in the tram type cities in Europe, tram networks are together with many other kinds of urban facilities. Tram networks represent a structure for locating urban facilities. The data that we gathered in this paper will help us to develop a city plan in relation to the tram network, 3) when we perform city planning we need to consider not only the location, but also to the accessibility to urban facilities. In 
order to make an adequate urban structure for pedestrian accessibility, the location of the urban facility is very important. We are able to offer the "package approach', including tram network and urban facilities, by paying attention to the location of the tram stop. This would be an important planning element. 4) Adequate location of the educational facility is a key point in order to design the tram network, and the connectively/accessibility to religious facilities represent that the tram network is also integrated into the historical conditions of these cities in Europe.

These findings in this paper help us to understand the urban structure of the tram type cities. The passengers who use the tram find it easy to reach several urban facilities from the station by walking, without worrying about vehicles on the streets. Thus, we are able to understand that the interior space of tram could perform like a square of the city. Trams help the pedestrian to move from one community area to another as a 'mobile public space'.

\section{References}

[1] http://europa.eu/rapid/pressReleasesAction.do

[2] The theme of the seminar was 'Traditional European Urbanism', which took place at Department of Architecture, Delft University of Technology, the Netherlands in October 2007.

[3] http://eurotram.web.infoseek.co.jp/lrt/link/link2.htm

[4] http://www.shugotram.jp/index.htm/

[5] http://www.shugotram.jp/index.htm/

[6] Suzuki Kenichi, 'Urban Politics on Infrastructure for the transportation: Making the logistic network in Europe [交通インフラ政策—欧州横断運輸ネットワークの構築］，

Department of National Transportation［国土交通課］, p.160

[7] Yamanaka, Hideo, 'Strategy for Town Planning by transportation System: Using Package Approach [まちづくりのための交通戦略— パッケージアプローチのすすめ] ', Gakugei Press, Kyoto, 2002, pp.104-108

[8] Doi Yasunori, 'Revitalization of Center Town Area by Introduction of LRT', Social Systems Studies, Vol.2, March, 2000, pp. 1-22

[9] Nishimura, Kaku \& Hattori, Shigetaka, 'City and Public Transportation: Transportation Politics and Transportation Facilities in the Western Countries [都市と路面公共交通：欧米にみる交通政策と施設］', Gakugei Press, Kyoto, Japan, December 2000, pp.18-19, p23, p33

[10] Matsunaka, Ryoji, 'A study on the influence by the introduction of LRT based on investigation of documents: case study in Strasbourg and Mulhouse', Journal of the City Planning Institute of Japan, No.43, 2008, pp. $811-816$

[11] Matsynaka Ryoji and others, 'Analysis about the influence of the LRT introduction on commercial activities in the city centre: Case study in Strasbourg［LRTが中心市街地の商業活動に及ぼした影響に関する分 
析一フランス・ストラスブールを対象として］， Journal of Japan Society of Civil Engineers Vol35［土木計画学講演集Vol.35］p.59

[12] Aoyama Yoshitaka (ed.),'LRT and Sustainable Town Planning: Enhancing Amenity of the city and Decreasing Ecological Foot Prints [LRTと持続可能まちづくり : 都市のアメニティの向上と環境 負荷の低減をめざして， Gakugei Press, Kyoto, 2008, p.30

[13] Hattori Shigetaka, 'The New Paradigm of Tram: Toward LRT [路面電車新時代：LRTへの軌跡］，Sankai Do Press, 2006, pp.62-67

[14] The Research Committee of Latest Urban Tram of the World (ed.), 'The Latest Trams of the World 2 [世界の最新型路面電車2] , The Tram Society of Japanese, Tokyo, 2001, pp.129-132

[15] Nishimura, Kaku \& Hattori, Shigetaka, 'City and Public Transportation: Transportation Politics and Transportation Facilities in the Western Countries［都市と路面公共交通：欧米にみる交通政策と施設］', Gakugei Press, Kyoto, Japan, December 2000, pp.18-19, p23, p33

[16] Nawada, Korehiko, 'Legal theory of the Community［コミュニティの法理論］ Sobunsha Press, Tokyo, 1998, p. 81

[17] The city map of Jena, Würzburg, Ulm, Kassel, Darmstadt, Neuss, Heidelberg, Heilbronn, Potsdam, and Ludwigshafen were made by Falk Verlag (Printed in Germany). The city map of Gera, Saarbrücken, and Rostock were made by ADAC (Printed in München). The city map of Orléans, Caen, Grenoble, St-Etienne, Nancy, Mulhouse and Le Mans were made by Blay Foldex (printed in France). The City map of Blackpool was made by Blackpool AZ; U21. Blackpool. The city map of Innsbruck, Salzburg, and Linz were made by FREYTAG. (printed in Austria).

[18] Yoshitake, Yasumi, 'Studies on Architectural Planning [建築設計計画研究拾遺] ', Chiba Printing, Tokyo, 2004年, p.61

[19] We regard the large community area as the area that is depicted in the city map.

[20] According to Dr. Nawada adequate community size is from hundred thousand to two hundred thousand from the examples of Bremen and Hamburg in Germany. On the other hand, the neighbourhood scale is a community [16], defined by Nawada, and the tram stop community in this paper is equivalent to the neighbourhood community.

[21] When we picked up one pedestrian area of which it is possible to distinguish that pedestrian streets are connected to each other.

[22] The number of mill and other urban facilities are less, thus we did not use these numbers in order to analyze the characteristics of the tram type cities.

[23] The program for cluster analysis used in this paper is made by Prof. Shigeo Aoki. He provides us several kinds of analysis programs on the Internet. The address of this program is as follows; http://aoki2.si.gunmau.ac.jp/BlackBox/BlackBox.html. We used his program in December 2008 . 